\title{
ENVIRONMENTAL APPROACH TO ASSESSMENT \\ OF THE RESPONSE OF HYDROECOSYSTEMS \\ TO ANTHROPOGENIC LOAD
}

\section{Iryna Shakhman ${ }^{1}$ \\ Anastasiia Bystriantseva ${ }^{2}$}

DOI: https://doi.org/10.30525/978-9934-588-15-0-142

Abstract. Assessment of the state of hydroecosystems and development of mechanisms for their rational use is one of the most important tasks of modern hydroecological research. The purpose of this paper is to estimate the water quality of the Lower Section of the Dnieper River (including the Lower Section of the Ingulets River) by different methods of determining the water quality of surface water bodies in accordance with fisheries standards, as being most sensitive to changes in the ecological state of the river, on the basis of monitoring over the years 2001-2016. Estimation of the quality of surface water within the Kherson region by different methods by hydrochemical parameters in accordance with the current standards of the quality of surface water resources was executed. It was found that by hydro-chemical parameters waters of the Lower Section of the Dnieper River are mostly "moderately contaminated" and "contaminated", waters of the Lower Section of the Ingulets River are mostly "contaminated", "very contaminated", or "catastrophically contaminated". Ecological state of the Lower Section of the Dnieper River and of the Lower Section of the Ingulets River was estimated by method of calculation of integrated index. The current calculation method takes into account the effect of the total action of substances and is approved practically for the analysis of the ecological state of other rivers. Self-purification potential and capability of restoration in time and space (along the river stream) of the aquatic ecosystem of the lower section of the Dnieper River and of the Lower Section of the Ingulets

\footnotetext{
${ }^{1}$ Candidate of Geographical Sciences, Associate Professor, Associate Professor of the Department of Ecology and Sustainable Development, Kherson State Agrarian University, Ukraine

${ }^{2}$ Candidate of Physical and Mathematical Sciences, Associate Professor, Associate Professor of the Department of Algebra, Geometry and Mathematical Analysis, Kherson State University, Ukraine
} 
River were established. It was discovered, that the state of surface water of region was characterized as unsteady with the low of ecological reliability. The monograph highlights the application of mathematical models in the hydroecological problems research. The analysis of anthropogenic factors affecting change of quality of the Dnieper River surface water was used. Consequently, the processes of self-purification potential and capability of the aquatic ecosystems restoration are at the low level. The ecological state of the rivers is characterized as an ecological regress. It was established that for today it is connected with certain ecological risks to consider the basin of the Lower Section of the Dnieper River as a water object of fishery significance. There is a necessity of further research using modern methods of complex estimation of surface waters sources' quality.

\section{Introduction}

Water resources are a source of industrial and domestic water supply, and therefore play a decisive role in the development of the economy and the life activity of the population. The level of water supply in Ukraine is insufficient, and the territorial division of the country's water resources is uneven and does not correspond to the location of water-containing economic complexes.

The main source of water supply for the population is river flow, but on average only $30 \%$ of the river flow falls on the southern economic region (Kherson, Nikolaev and Odessa regions). In this regard, in many areas of southern Ukraine there is an acute shortage of water, for the elimination of which it is necessary to transfer water through canals, build reservoirs, etc. Due to increasing anthropogenic load on river basins, issues of environmental assessment of the hydroecosystems of Low Podneproviya (the Lower Section of the Dnieper River and the Lower Section of the Ingulets River) deserve special attention.

The intensive economic use of water resources enhances anthropogenic stress on water bodies, which leads to a change in the water balance, dynamic characteristics and hydrophysical properties of water masses and bottom sediments. These changes are often so powerful that influence on the regime of ecosystems biotic components. There are frequent cases when the changes of even some elements of the natural water bodies hydrological regime cause a noticeable and sometimes radical transformation of indi- 
vidual sections or aquatic ecosystems in general [1, p. 259]. An example is the cascade of the Dnieper reservoirs [2, p. 181]. Theirs total reservoir capacity is greater in 14 times than the river bed volume of the Dnieper River, and as a result the velocity of currents decreased in 30-40 times, water turbidity - in 7-9 times. The wind-wave processes, lowering-raising of the water level by the effect of wind processes and seiches were activated, the temperature regime was changed. All this created the conditions for changing the species composition and productivity of live organisms. The listed effects reflect changes in the structure and functioning of aquatic ecosystems, demonstrating the dependence of biological processes of production-destruction of organic matters (self-purification potential and capability of restoration) by hydrochemical parameters [3, p. 75; 4, p. 103], and may lead to the aquatic ecosystems' destruction [1, p. 259; 4, p. 104]. Modern scientists' experience allows on the basis of the analysis of the water exchange processes and formation of the water quality $[1$, p. 259 ; 5 , p. $119 ; 6$, p. $113 ; 7$, p. $445 ; 8$, p. 127] to predict the consequences of the organic matter development [2, p. 181] and the capability of restoration of the aquatic ecosystem [4, p. 104; 6, p. 113]. The hydroecologists' purpose suggests, by using models of water quality dependencies and bioproductivity from water exchange, to react promptly on changes of the water ecosystem state and manage of the water quality of the cascade of reservoirs for anthropogenic pollution reduction or elimination of water bodies [6, p. 113; 7, p. 445; 8, p. 127].

\section{Mathematical model of the ecological state}

Water quality assessment is a key task in the field of water use, environmental management and environmental protection measures for water bodies and their basins. Water quality is assessed by a wide range of indicators - biological (hydrobiological, bacteriological) and physico-chemical (hydrochemical, hydrophysical, hydrological). Biological methods based on assessing the state of the flora and fauna of water resources are widely used to determine the ecological state of a water body.

One of the main qualitative indicators of water bodies is their hydrochemical regime, which is determined by the influence of many factors: the dynamics of runoff, naturally climatic conditions, the intensity of human economic activity, etc. The use of physical and chemical methods involves 
the determination of abiotic factors: temperature, water clarity, concentrations of suspended solids, ionic composition, mineralization, concentration of nutrients, organic matter, oxygen dissolved in water, various toxins, $\mathrm{pH}$, etc. Traditionally, water quality is determined by chemical methods. System analysis of existing methods for determining the quality of natural waters has shown the effectiveness of the use of integrated indicators.

Assessment of the ecological state of water bodies is reduced to an analysis of the proximity of the actual values of water parameters with the maximum allowable [9, p. 20]. However, the regulated number of water parameters is large. So, for freshwaters for domestic and cultural use, there are 1345 , and for water objects for fishery use -521 . Therefore, it is rational to determine the ecological state of a water body using a complex indicator that relates water parameters to maximum permissible values.

The modern calculation method [9, p. 20] allows to determine quickly the ecological state of the aquatic ecosystem by the hydrochemical parameters. It also allows according to the ecological state integrated indices of the water body to assess its ability to self-purification potential and capability of restoration (ecological reliability), to analyze the ecological sustainability of the river and to take into account the effect of the total action of substances. Integrated index of the ecological state (IIES) is formed on the basis of existing standards and also includes maximum permissible concentrations (MPC).

Assessment of the ecological state of the Lower Section of the Dnieper River and of the Lower Section of the Ingulets River was performed on the integrated index of the ecological state (IIES) $[9$, p. 20] in accordance with the fishery standards, as the most sensitive to changes in the ecological state of the river. For water bodies which are used for the fishery use, the mean value of IIES is calculated by the formula:

$$
\text { IIES } S_{\text {mean }}=\frac{1}{m} \sum_{i=1}^{m} I I E S_{i},
$$

where $m$ - number of water quality indices blocks (values $I I E S_{i}$ ).

From the $m$ blocks of water quality indices, the first includes indices that don't have the effect of total action (summation), the remaining blocks include indices that have this effect. According to the sanitary norms, the effect of total action is possessed by substances of the first and second classes of danger with the equal limiting indices of harmfulness (LIH). 
According to the fishery norms substances with the equal LIH without taking into account the classes of danger are analyzed.

The ecological state of a water body is classified as follows:

- if $I I E S_{\min }<0$ and IIES $S_{\text {mean }}<0$ then the ecological state of the river area is estimated as unsteady;

- if $I I E S_{\min }<0$ and $I I E S_{\text {mean }}>0$ then the ecological state of water is estimated on average as stable with sources of instability;

- if $I I E S_{\min }>0$ and IIES $S_{\text {mean }}>0$ then the ecological state of water is estimated as stable.

In the qualification of the ecological state according to the first two points it is necessary to carry out environmental protection activities in the ecosystem. The obtained results allow carrying out an assessment of the ecological reliability of the ecosystem [9, p. 20]. Ecological reliability (ER) is the ability of the ecosystem's state to perform relatively complete processes of self-purification potential and capability of restoration.

The probability of a stable state of the river is called ecological reliability (ER), which is determined by the formula:

$$
E R=1-\chi^{2} /\left(2 N-M+0,5 \chi^{2}\right),
$$

where $\chi^{2}$ - the value of the function "chi-square" with the confidence probability assumed equal to $0,9[10$, p. 370$] ; \mathrm{N}-$ the total number of values $I I E S_{\text {mean }} ; \mathrm{M}$ - the number of values IIES $S_{\text {mean }}$ which are less then the critical, zero value.

Distribution probability of "chi-squared" recognizing right in connection with the fact that usually the number of surveyed sections of the river is small. For a large value of N, the "chi-squared" distribution reduces to a normal distribution. Based on the fact that complex technical systems are considered reliable at a reliability level of $0,90-0,95$, the following qualification of reliability levels is used with a confidence level of 0,9 : a high level $(E R \geq 0,9)$, an acceptable level $(0,9>E R \geq 0,8)$, a low level $(E R<0,8)[9$, p . 20].

\section{Modeling process of self-purification of hydroecosystems}

The results of studies of the surface waters of the Lower Section of the Dnieper River indicate constant water pollution and excess maximum permissible concentrations (MPS) of substances (Iron, Total ammonium, Sulphates and others). The main negative factors that change the water 
quality of the Dnieper River are regulation of runoff, discharges of industrial and agricultural wastewater, and the built up sanitary protection zones. The main seasonal factors affecting the quality of surface waters are intense erosion-hazardous rains and snowmelt, which lead to the flushing of a large number of various pollutants with surface soil particles and their accumulation in water bodies; high summer temperature or heat, which stimulates mass flowering of green algae in the Dnieper River, rotting processes; a reduction of oxygen in water leads to a significant deterioration in its physico-chemical and trophic state and a massive pestilence of fish.

The data of the analytical monitoring of surface waters of the Kherson Water Resources Board was used to assess the ecological state of the Lower Section of the Dnieper River on points of supervisions of water: 1 - the Dnieper River - town Novovorontsovka-Ushkalka, Kakhovka Reservoir (195 km from the mouth), 2 - the Dnieper River - low tail-water of Kakhovka HPS (92 km from the mouth), 3 - the Dnieper River - city Kherson, $1 \mathrm{~km}$ upstream the city (40 km from the mouth), 4 - the Dnieper River village Kizomys, arm of a river Rvach (0 km from the mouth) (Figure 1).

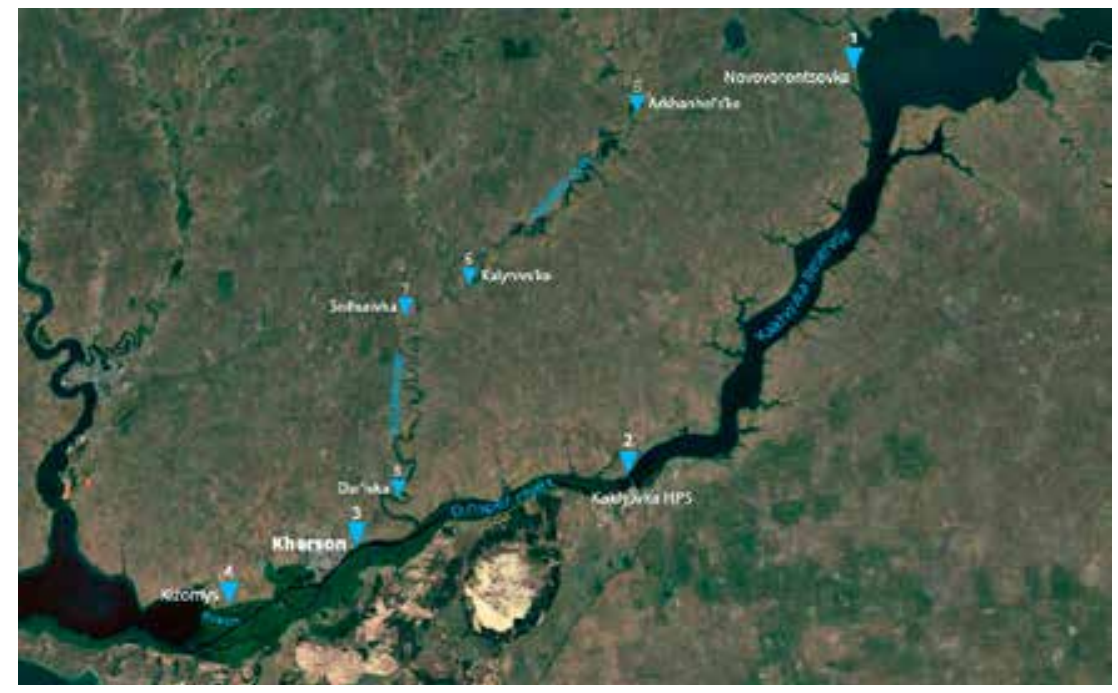

Figure 1. Scheme of the Lower Section of the Dnieper River and the Lower Section of the Ingulets River 
The initial data for assessing the ecological state of waters in the Lower Section of the Ingulets River are the results of analytical control of surface waters by the State Ecological Inspectorate in Kherson region: 5 - the Ingulets River - village Arkhanhel's'ke (210 km from the mouth), 6 - the Ingulets River - village Kalynivs'ke (124 km from the mouth), 8 - the Ingulets River - village Dar'ivka (20 km from the mouth) and the State Ecological Inspectorate in Mykolaiv region: 7 - the Ingulets River town Snigurivka (100 km from the mouth) (Figure 1).

The results of recent studies of the surface waters of the Lower Section of the Dnieper River indicate constant water pollution and excess maximum permissible concentrations (MPS) of substances (Total ammonium, Suspended solids, Chlorides, Sulphates, Petroleum hydrocarbons, Iron, Copper, Manganese and others) (Figure 2) [8, p. 127; 11, p. 265; 12, p. 123; 13 , p. 260; 14, p. 44].

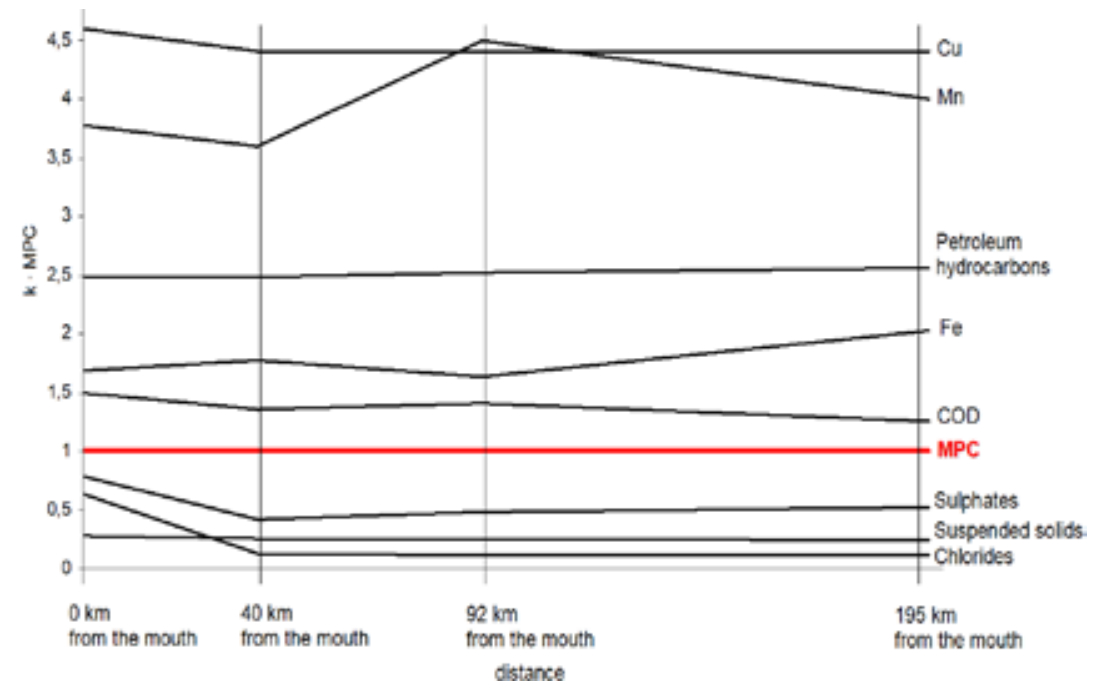

Figure 2. Excess annual average values (2013-2016) of hydrochemical ingredi-ents relative to MPC of the Lower Section of the Dnieper River

For the Lower Section of the Ingulets River, the maximum permissible concentration for Sulphates, Chlorides, Suspended solids, Iron and other 
substances (Figure 3, 4, 5, 6) are most often observed, which indicates that the main source of pollution is discharges of highly mineralized polluted industrial effluents of the city Kryvyi Rih serving the mining, metallurgical and chemical industries. In the Kryvyi Rih basin, 8 of 11 Ukrainian enterprises for the extraction and processing of iron ore are located. Here are enterprises serving the metallurgical industry - one of the world's largest metallurgical plants (PJSC “ArcelorMitall Kryvyi Rih"), five mining and processing combines (MPC) - Pivnichnyi MPC (PivnMPC), Pivdennyi MPC (PivdMPC), Cental'nyi MPC (CMPC), Novokryvoriz'ky MPC (NKMPC), Ingulets'kiy MPC (InMPC), three ore repair plants.

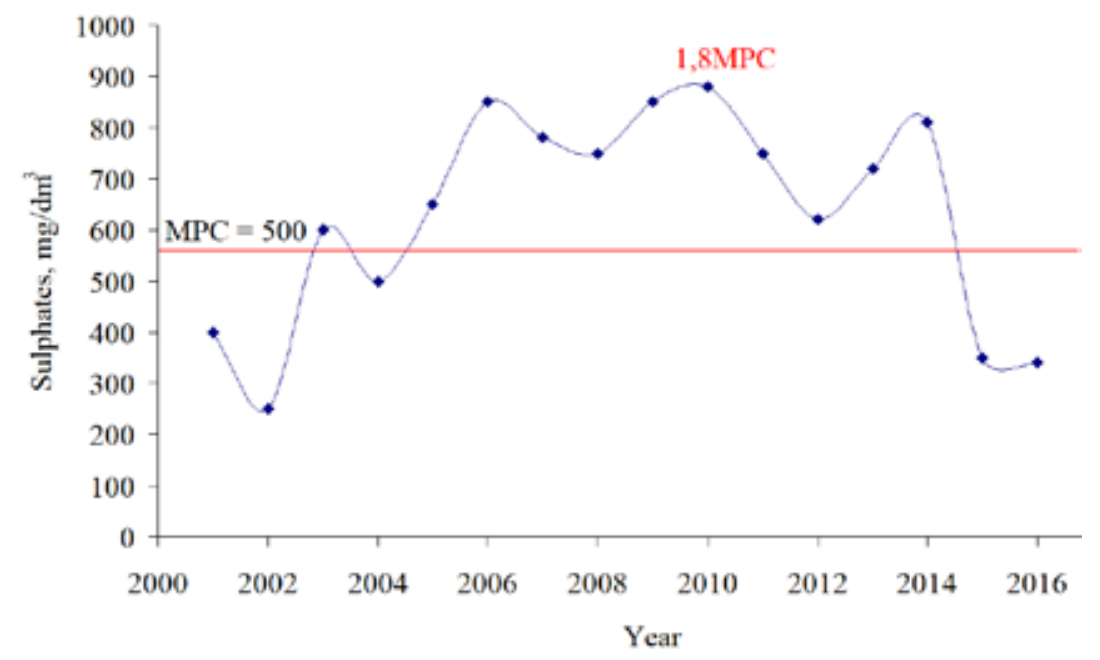

Figure 3. The dynamics of changes in the concentration of Sulfates in the Lower Section of the Ingulets River

The volume of wastewater of enterprises reaches millions of cubic meters per year, which negatively affects the quality of the water of the Ingulets River, which carries its polluted water to the Lower Section of the Dnieper River.

In the late 60 s of the last century, in connection with the implementation of state programs for irrigation and drainage construction, the construction of large irrigation canals began, which at the same time solved the problems 


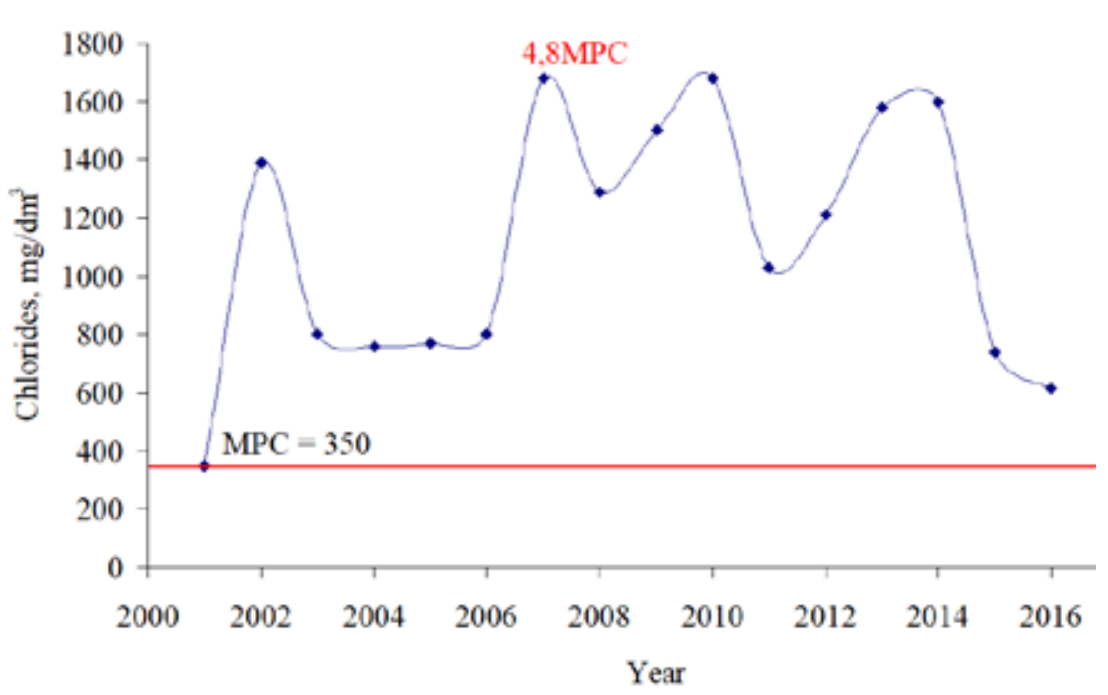

Figure 4. The dynamics of changes in the concentration of Chlorides in the Lower Section of the Ingulets River

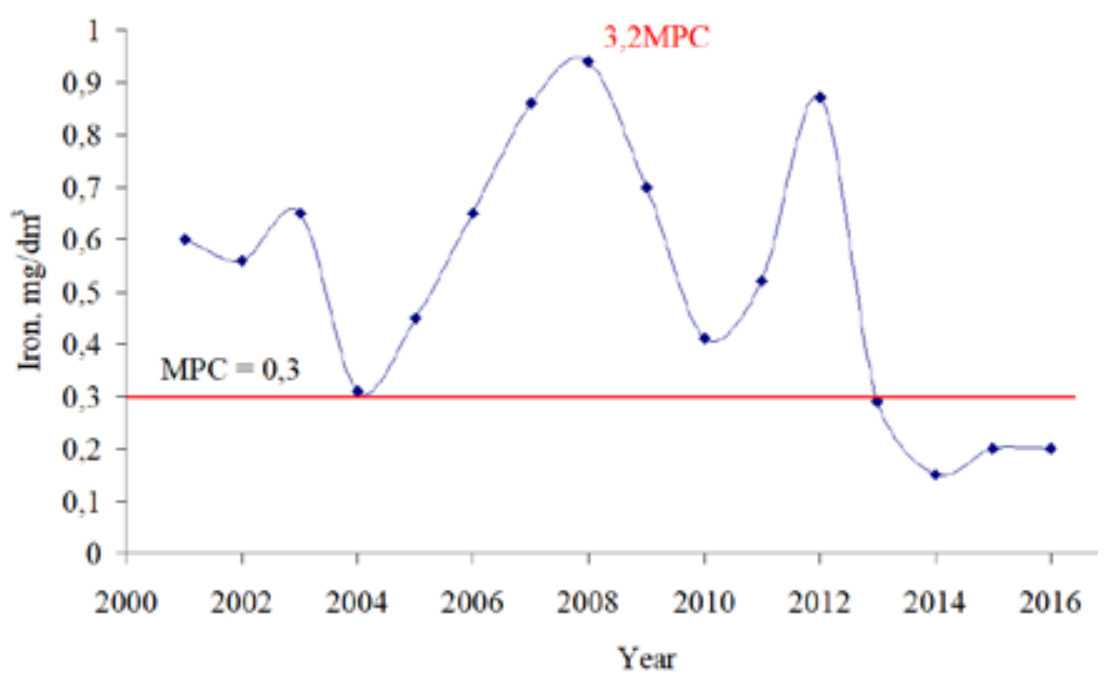

Figure 5. The dynamics of changes in the concentration of Iron in the Lower Section of the Ingulets River 


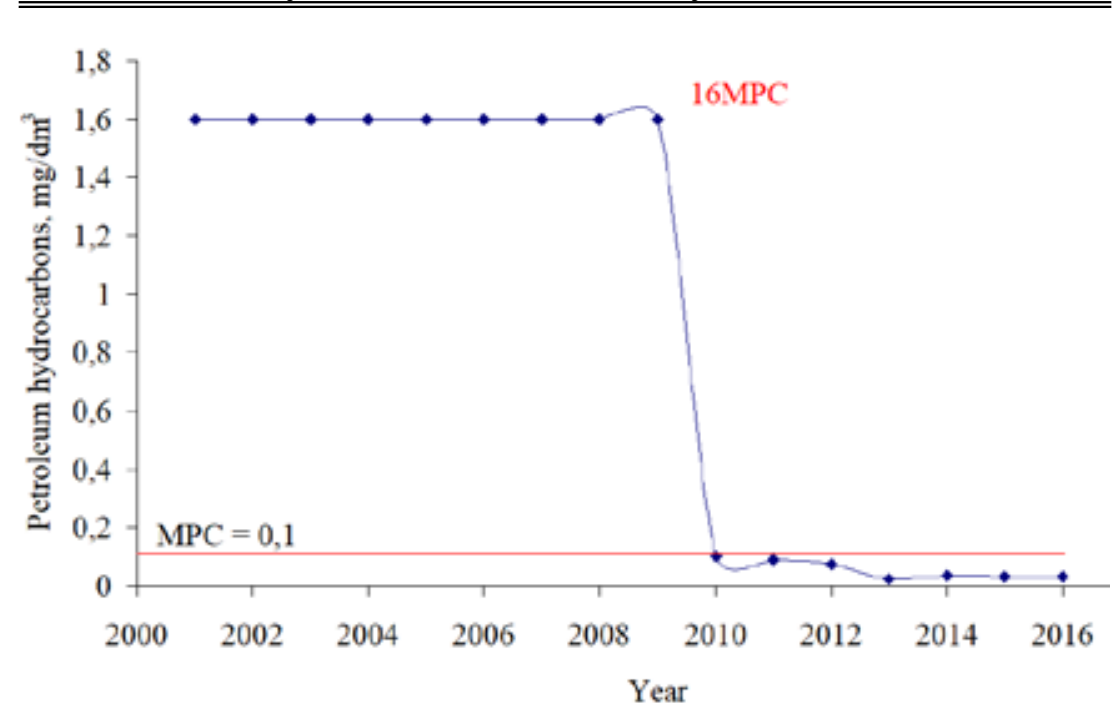

Figure 6. The dynamics of changes in the concentration of Petroleum Hydrocarbons in the Lower Section of the Ingulets River

of water supply for nearby settlements and industrial centers. The idea of expanding irrigated areas in the arid steppes of the south of the Nikolaev region was laid down in the Danube- Dnieper Canal project and was partially implemented through the operation of the Ingulets Canal (1989). Due to the transfer of runoff from the Dnieper River (donor river), the annual runoff of the Ingulets River increases. In addition, the additional flow of water into the Ingulets River occurs due to the formation of reverse filtration water from agricultural lands that are irrigated by the Dnieper River. During the transition to more arid territories, the influence of anthropogenic activity increases, and despite the artificial increase in the water exchange of the Ingulets River, the ecological state of the watercourse does not improve, since polluted waters enter the river. The agricultural development of the study area is quite high (the area of agricultural land is $69,2 \%$ ), therefore, the application of pesticides leads to pollution of the soil with toxic elements, and the flowing of water from the fields by the surface and filter-ing cause the migration of carcinogens to the nearest water body - to the Ingulets River. In the mixed waters of the Ingulets and Dnieper Rivers (irrigation area 37140 hectares), the chemical 
composition is chloride-sulfate-hydrocarbonate, sulfate-chloride, sodium-calcium-magnesium with a total mineralization of up to $3,5 \mathrm{~g} / \mathrm{dm}^{3}$ (downstream the Karachunivs'ke reservoir).

The main seasonal factors affecting the quality of the surface waters of the Lower Section of the Dnieper River are intense erosion-hazardous rains and snowmelt, which lead to the flushing of a large number of various pollutants with surface particles of the soil and their accumulation in water bodies. High summer temperature or heat, which stimulates mass flowering of green algae in the Dnieper River, rotting processes; a reduction of oxygen in water leads to a significant deterioration in its physico-chemical and trophic state and a massive pestilence of fish.

The effect of the total action of the factors describe above forms the hydro-chemical marks of the water bodies of the Lower Section of the Dnieper River and determines the qualitative composition of the surface runoff. The processes of formation of the chemical composition of water occur under the influence of a powerful anthropogenic load on water resources, the consequences of which are amplified in conditions of global warming. In this regard, it is very important not only observation and control, but also timely analysis of changes in hydrochemical marks in time and space, a reliable assessment of water quality.

As a result of the study, a complex assessment of the water quality of the Lower Sections of the Dnieper River and the Ingulets River was carried out using different methods in accordance with the water quality standards of surface water bodies for fishery purposes. It was found that the water quality of the Lower Section of the Dnieper River according to different methods (water pollution index, modified water pollution index, combinatorial water pollution index and integrated assessment method) varies from "moderately contaminated" to "contaminated". Study of waters quality indicators of the Lower Section of the Ingulets River, determined based on the application of the same calculation methods to hydrochemical data, showed, that waters are mostly "contaminated", "very contaminated", or "catastrophically contaminated". Therefore, there is a need to assess the ecological state of the Low Podniproviya hydroecosystem using a complex indicator that relates water parameters to the maximum permissible indicators, namely, with the help of a complex indicator of the eco-logical state. The obtained complex indicators allow us to move on to assessing the environmental reliability of 
water bodies - the ability of a hydroecosystem to full relatively self-purification and self-regulation.

The Integrated indices calculation of the ecological state of the Lower Section of the Dnieper River according to the fishery norms was made. An example of assessing the ecological state of a water body by using integrated index IIES on gauge station the Dnieper River - village Kizomys, arm of a river Rvach (0 km from the mouth) for observations in 2016 according to the fishery norms is presented in Table 1 .

Table 1

\section{Assessment of water quality of the Dnieper River - village Kizomys,} arm of a river Rvach (0 $\mathrm{km}$ from the mouth) according

to the integrated index IIES fol-lowing to the fishery norms for 2016

\begin{tabular}{|c|c|c|c|c|c|c|}
\hline LIH & Parameter & $\begin{array}{c}C_{\mathrm{i}} \\
\mathbf{m g} / \mathbf{d m}^{3}\end{array}$ & $\begin{array}{c}\text { MPS } \\
\mathbf{m g} / \mathbf{d m}^{3}\end{array}$ & $\begin{array}{c}\text { MPS - } \\
\text { C }_{i}\end{array}$ & IES & IIES \\
\hline \multirow{4}{*}{$\begin{array}{l}\text { General } \\
\text { health }\end{array}$} & Suspended solids & 5,0 & 20,0 & 15,0 & 0,75 & \\
\hline & $\mathrm{BOD}_{5}$ & 1,63 & 3,0 & 1,37 & 0,46 & \\
\hline & $\mathrm{pH}$ & 7,91 & $6,5-8,5$ & 0,59 & 0,07 & \\
\hline & Dissolved oxygen & 10,0 & 6,0 & $-4,0$ & $-0,67$ & \\
\hline \multicolumn{5}{|c|}{$\Sigma$} & 0,61 & 0,15 \\
\hline \multirow{6}{*}{ Toxicological } & Saline ammonia & 0,12 & 0,50 & - & 0,24 & \\
\hline & Nitrites & 0,03 & 0,08 & - & 0,38 & \\
\hline & ASAS & 0,01 & 0,50 & - & 0,02 & \\
\hline & \begin{tabular}{|l|} 
Iron \\
\end{tabular} & 0,12 & 0,10 & - & 1,2 & \\
\hline & Copper & 0,01 & 0,001 & - & 10,0 & \\
\hline & Manganese & 0,05 & 0,01 & - & 5,0 & \\
\hline \multicolumn{5}{|c|}{$\Sigma$} & 16,84 & $-15,84$ \\
\hline \multirow{6}{*}{$\begin{array}{l}\text { Sanitary- } \\
\text { toxicological }\end{array}$} & Chlorides & 82,0 & 300 & - & 0,27 & \\
\hline & Sulphates & 68,4 & 100 & - & 0,68 & \\
\hline & Calcium & 48,0 & 180 & - & 0,27 & \\
\hline & Nitrates & 0,93 & 40,0 & - & 0,02 & \\
\hline & Chrome & 0,001 & 0,001 & - & 1,00 & \\
\hline & Magnesium & 18,3 & 40,0 & - & 0,46 & \\
\hline \multicolumn{5}{|c|}{ 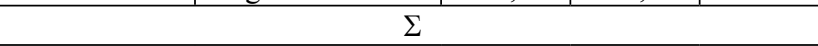 } & 2,70 & $-1,70$ \\
\hline Fishery & $\begin{array}{l}\text { Petroleum } \\
\text { hydro-carbons }\end{array}$ & 0,3 & 0,05 & - & 6,00 & $-5,00$ \\
\hline
\end{tabular}


Summary results of the assessment of the ecological state of the Lower Section of the Dnieper River in time and in space (along the river stream) over the period of 2013-2016 are presented in Table 2.

Table 2

Assessment of Ecological State of the Lower Section of the Dnieper River in space (along the river stream) and time over the years 2013-2016

\begin{tabular}{|c|c|c|c|c|c|c|c|c|}
\hline \multirow{4}{*}{$\begin{array}{l}\text { Gauge } \\
\text { station }\end{array}$} & \multicolumn{8}{|c|}{ Integrated index of the ecological state (IIES) } \\
\hline & $\min$ & mean & $\min$ & mean & $\min$ & mean & $\min$ & mean \\
\hline & \multicolumn{8}{|c|}{ ecological state of a water body } \\
\hline & \multicolumn{2}{|c|}{2013} & \multicolumn{2}{|c|}{2014} & \multicolumn{2}{|c|}{2015} & \multicolumn{2}{|c|}{2016} \\
\hline \multirow{2}{*}{1} & $-2,2$ & $-0,6$ & $-3,7$ & $-1,0$ & $-16,2$ & $-5,7$ & $-17,2$ & $-5,9$ \\
\hline & \multicolumn{2}{|c|}{ unsteady } & \multicolumn{2}{|c|}{ unsteady } & \multicolumn{2}{|c|}{ unsteady } & \multicolumn{2}{|c|}{ unsteady } \\
\hline \multirow{2}{*}{2} & $-2,2$ & $-0,5$ & $-4,2$ & $-1,1$ & $-17,1$ & $-5,1$ & $-16,8$ & $-5,8$ \\
\hline & \multicolumn{2}{|c|}{ unsteady } & \multicolumn{2}{|c|}{ unsteady } & \multicolumn{2}{|c|}{ unsteady } & \multicolumn{2}{|c|}{ unsteady } \\
\hline \multirow{2}{*}{3} & $-2,1$ & $-0,5$ & $-2,9$ & $-0,8$ & $-16,2$ & $-5,6$ & $-15,7$ & $-5,5$ \\
\hline & \multicolumn{2}{|c|}{ unsteady } & \multicolumn{2}{|c|}{ unsteady } & \multicolumn{2}{|c|}{ unsteady } & \multicolumn{2}{|c|}{ unsteady } \\
\hline \multirow{2}{*}{4} & $-2,3$ & $-0,7$ & $-3,5$ & $-1,3$ & $-16,0$ & $-4,8$ & $-15,8$ & $-5,6$ \\
\hline & \multicolumn{2}{|c|}{ unsteady } & \multicolumn{2}{|c|}{ unsteady } & \multicolumn{2}{|c|}{ unsteady } & \multicolumn{2}{|c|}{ unsteady } \\
\hline
\end{tabular}

Dnieper River in time and in space (along the river stream) is estimated as un-steady. Dynamics of quantitative parameters of mean and minimum coefficients demonstrates deterioration of river water quality in time. For the observation period 2013-2016, the environmental reliability (ER) was assessed in time and in space (along the river stream). The values of environmental reliability were calculated $(\mathrm{ER}=0,74)$, which corresponds to a low level of self-purification potential and capability of restoration.

The dynamics of the results of the studies in time (Table 2) demonstrates the increase of the negative consequences of anthropogenic load and the need for the implementation of environmental events aimed at renewing the ability of the aquatic ecosystem to self-purification and capability of restoration.

The calculation of the integrated indicators of the ecological state of the waters for the gauge station of the Ingulets River - town Snigurivka in 
accordance with the requirements of fishery water use for the observation period 2001-2016 was completed. An example of assessing the ecological state of a water body using the integrated index IIES for the gauge station of the Ingulets River - town Snigurivka for 2014 observation period due to the fishery norms is given in table 3 .

Table 3

Assessment of water quality of the Ingulets River - town Snigurivka $(100 \mathrm{~km}$ from the mouth) according to the integrated index IIES following to the fishery norms for 2014

\begin{tabular}{|c|c|c|c|c|c|c|}
\hline LIH & Parameter & \begin{tabular}{c|}
$\mathrm{C}_{\mathrm{i}}$ \\
$\mathbf{m g} / \mathbf{d m}^{3}$
\end{tabular} & $\begin{array}{c}\text { MPS } \\
\mathbf{m g} / \mathbf{d m}^{3}\end{array}$ & $\begin{array}{c}\text { MPS - } \\
\mathbf{C}_{i}\end{array}$ & IES & IIES \\
\hline \multirow{4}{*}{$\begin{array}{l}\text { General } \\
\text { health }\end{array}$} & Suspended solids & 40,2 & 20,0 & $-20,2$ & $-1,01$ & \\
\hline & $\mathrm{BOD}_{5}$ & 4,9 & 3,0 & $-1,9$ & $-0,63$ & \\
\hline & $\mathrm{pH}$ & 7,6 & $6,5-8,5$ & 0,9 & 0,11 & \\
\hline & Dissolved oxygen & 11,4 & 6,0 & 5,4 & 0,90 & \\
\hline \multicolumn{5}{|c|}{$\Sigma$} & $-0,63$ & $-0,17$ \\
\hline \multirow{6}{*}{ Toxicological } & Saline ammonia & 0,43 & 0,50 & - & 0,86 & \\
\hline & Nitrites & 0,071 & 0,08 & - & 0,89 & \\
\hline & ASAS & 0,019 & 0,50 & 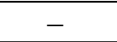 & 0,04 & \\
\hline & \begin{tabular}{|l|} 
Iron \\
\end{tabular} & 0,148 & 0,10 & - & 1,48 & \\
\hline & Copper & 0,006 & 0,001 & - & 6,0 & \\
\hline & Manganese & 0,003 & 0,01 & - & 0,30 & \\
\hline \multicolumn{5}{|c|}{ D } & 9,57 & $-8,57$ \\
\hline \multirow{5}{*}{$\begin{array}{l}\text { Sanitary- } \\
\text { toxicological }\end{array}$} & Chlorides & 1588,4 & 300 & - & 5,29 & \\
\hline & \begin{tabular}{|l|} 
Sulphates \\
\end{tabular} & 823,5 & 100 & - & 8,24 & \\
\hline & Calcium & 172,4 & 180 & - & 0,96 & \\
\hline & Nitrates & 9,9 & 40,0 & - & 0,25 & \\
\hline & Chrome & 0,001 & 0,001 & - & 1,00 & \\
\hline \multicolumn{5}{|c|}{$\Sigma$} & 15,74 & $-14,7$ \\
\hline Fishery & $\begin{array}{l}\text { Petroleum } \\
\text { hydro-carbons }\end{array}$ & 0,04 & 0,05 & - & 0,80 & 0,2 \\
\hline
\end{tabular}

The summary results of the assessment of the ecological state of the river for the gauge station of the Ingulets River - town Snigurivka in time are given in Table 4. 
During the observation period (2001-2016), the ecological state of the Lower Section of the Ingulets River in time is estimated as unsteady. Dynamics of quantitative parameters of mean and minimum coefficients demonstrates deterioration of river water quality in time. For the observation period 2001-2016, the environmental reliability (ER) was assessed in time. The values of environmental reliability were calculated $(\mathrm{ER}=0,56)$, which corresponds to a low level of self-purification potential and capability of restoration.

Table 4

\section{Assessment of Ecological State of the Lower Section of the Ingulets River in time over the years 2001-2016}

\begin{tabular}{|c|c|c|c|}
\hline \multirow{2}{*}{ Year } & \multicolumn{2}{|c|}{$\begin{array}{c}\text { Integrated index of the ecological state } \\
\text { (IIES) }\end{array}$} & $\begin{array}{c}\text { The ecological state } \\
\text { of the water object }\end{array}$ \\
\cline { 2 - 3 } & IIES $_{\text {mean }}$ & IIES $_{\text {min }}$ & unsteady \\
\hline 2001 & $-15,3$ & $-31,0$ & unsteady \\
\hline 2002 & $-15,3$ & $-31,0$ & unsteady \\
\hline 2003 & $-16,9$ & $-31,0$ & unsteady \\
\hline 2004 & $-14,0$ & $-31,0$ & unsteady \\
\hline 2005 & $-14,9$ & $-31,0$ & unsteady \\
\hline 2006 & $-19,1$ & $-31,6$ & unsteady \\
\hline 2007 & $-22,3$ & $-42,5$ & unsteady \\
\hline 2008 & $-20,0$ & $-32,4$ & unsteady \\
\hline 2009 & $-15,5$ & $-31,0$ & unsteady \\
\hline 2010 & $-7,9$ & $-15,4$ & unsteady \\
\hline 2011 & $-7,3$ & $-16,3$ & unsteady \\
\hline 2012 & $-7,8$ & $-19,2$ & unsteady \\
\hline 2013 & $-6,7$ & $-13,8$ & unsteady \\
\hline 2014 & $-5,8$ & $-14,7$ & unsteady \\
\hline 2015 & $-7,2$ & $-20,0$ & unsteady \\
\hline 2016 & $-6,9$ & $-19,8$ & \\
\hline
\end{tabular}

Assessment of the ecological state and ecological reliability of the Lower Sec-tion of the Ingulets River aquatic ecosystem along the length has also been performed (the gauge stations: the Ingulets River - village Arkhanhel's'ke, the Ingulets River - village Kalynivs'ke, the Ingulets River - town Snigurivka, the Ingulets River - village Dar'ivka) for 2013-2016. An exam- 
ple of assessing the ecological state of the water body in the gauge station the Ingulets River - village Dar'ivka for observations in 2016 according to fishery norms is given in table 5 .

Summary results of the assessment of the ecological state of the Lower Section of the Ingulets River in time and in space (along the river stream) over the period of 2013-2016 are presented in Table 6.

Table 5

Assessment of water quality of the Ingulets River - village Daryivka (20 $\mathrm{km}$ from the mouth) according to the integrated index IIES following to the fishery norms for 2016

\begin{tabular}{|c|c|c|c|c|c|c|}
\hline LIH & Parameter & $\underset{\mathbf{m g} / \mathbf{d m}^{3}}{\mathbf{C}_{\mathbf{m}^{3}}}$ & $\begin{array}{c}\text { MPS } \\
\mathbf{m g} / \mathbf{d m}^{3}\end{array}$ & $\begin{array}{c}\text { MPS - } \\
\mathbf{C}_{i}\end{array}$ & IES & IIES \\
\hline \multirow{4}{*}{$\begin{array}{l}\text { General } \\
\text { health }\end{array}$} & Suspended solids & 16,4 & 20,0 & 3,6 & 0,18 & \\
\hline & $\mathrm{BOD}_{5}$ & 3,9 & 3,0 & $-0,9$ & $-0,30$ & \\
\hline & $\mathrm{pH}$ & 8,05 & $6,5-8,5$ & 0,45 & 0,053 & \\
\hline & Dissolved oxygen & 9,8 & 6,0 & 3,8 & 0,63 & \\
\hline \multicolumn{5}{|c|}{$\Sigma$} & 0,56 & 0,14 \\
\hline \multirow{6}{*}{ Toxicological } & Saline ammonia & 0,14 & 0,50 & - & 0,28 & \\
\hline & Nitrites & 0,04 & 0,08 & - & 0,50 & \\
\hline & ASAS & 0,04 & 0,50 & - & 0,08 & \\
\hline & Iron & 0,19 & 0,10 & - & 1,87 & \\
\hline & Copper & 0,01 & 0,001 & - & 10,0 & \\
\hline & Manganese & 0,07 & 0,01 & - & 7,00 & \\
\hline \multicolumn{5}{|c|}{$\Sigma$} & 19,73 & $-18,73$ \\
\hline \multirow{5}{*}{$\begin{array}{l}\text { Sanitary- } \\
\text { toxicological }\end{array}$} & Chlorides & 613,7 & 300 & - & 2,05 & \\
\hline & Sulphates & 336,7 & 100 & - & 3,37 & \\
\hline & Calcium & 103,7 & 180 & - & 0,58 & \\
\hline & Nitrates & 2,15 & 40,0 & - & 0,05 & \\
\hline & Chrome & 0,001 & 0,001 & - & 1,00 & \\
\hline \multicolumn{5}{|c|}{$\Sigma$} & 7,05 & $-6,05$ \\
\hline Fishery & $\begin{array}{l}\text { Petroleum } \\
\text { hydro-carbons }\end{array}$ & 0,03 & 0,05 & - & 0,60 & 0,40 \\
\hline \multicolumn{7}{|c|}{$\begin{array}{l}\mathrm{IIES}_{\text {mean }}=(0,14-18,73-6,05+0,40) / 4=-6,06, \\
\text { (the ecological state of the object is unsteady) }\end{array}$} \\
\hline
\end{tabular}


During the period of research, the ecological state of the Lower Section of the Ingulets River is assessed as unsteady. A slight improvement in water quality from 2010 to 2014 [11, p. 265; 12, p. 123] is explained by the implementation for PJSC “ArcelorMitall Kryvyi Rih" an environmental monitoring system for wastewater and modern treatment facilities, as well as the annual "flushing" of the Ingulets river bed

with Dnieper water [15, p. 28], transported along the Dnieper-Ingulets Canal. In accordance with the regulation of channel flushing and rehabilitation of the Ingulets River, during April-July 2018, the State Water Agency discharged water from the

Table 6

\section{Assessment of Ecological State of the Lower Section} of the Ingulets River in space (along the river stream) and time over the years 2013-2016

\begin{tabular}{|c|c|c|c|c|c|c|c|c|}
\hline \multirow{4}{*}{$\begin{array}{l}\text { Gauge } \\
\text { station }\end{array}$} & \multicolumn{8}{|c|}{ Integrated index of the ecological state (IIES) } \\
\hline & $\min$ & mean & $\min$ & mean & $\min$ & mean & $\min$ & mean \\
\hline & \multicolumn{8}{|c|}{ ecological state of a water body } \\
\hline & \multicolumn{2}{|c|}{2013} & \multicolumn{2}{|c|}{2014} & \multicolumn{2}{|c|}{2015} & \multicolumn{2}{|c|}{2016} \\
\hline \multirow{2}{*}{5} & $-11,2$ & $-4,7$ & $-7,5$ & $-3,6$ & $-19,6$ & $-6,9$ & $-17,4$ & $-6,6$ \\
\hline & \multicolumn{2}{|c|}{ unsteady } & \multicolumn{2}{|c|}{ unsteady } & \multicolumn{2}{|c|}{ unsteady } & \multicolumn{2}{|c|}{ unsteady } \\
\hline \multirow{2}{*}{6} & $-7,8$ & $-3,5$ & $-7,9$ & $-3,5$ & $-19,7$ & $-6,8$ & $-18,3$ & $-6,7$ \\
\hline & \multicolumn{2}{|c|}{ unsteady } & \multicolumn{2}{|c|}{ unsteady } & \multicolumn{2}{|c|}{ unsteady } & \multicolumn{2}{|c|}{ unsteady } \\
\hline \multirow{2}{*}{7} & $-13,3$ & $-6,6$ & $-14,7$ & $-5,7$ & $-20,0$ & $-7,2$ & $-19,8$ & $-6,9$ \\
\hline & \multicolumn{2}{|c|}{ unsteady } & \multicolumn{2}{|c|}{ unsteady } & \multicolumn{2}{|c|}{ unsteady } & \multicolumn{2}{|c|}{ unsteady } \\
\hline \multirow[b]{2}{*}{8} & $-10,2$ & $-3,7$ & $-8,6$ & $-3,2$ & $-18,9$ & $-6,2$ & $-18,7$ & $-6,1$ \\
\hline & \multicolumn{2}{|c|}{ unsteady } & \multicolumn{2}{|c|}{ unsteady } & \multicolumn{2}{|c|}{ unsteady } & \multicolumn{2}{|c|}{ unsteady } \\
\hline
\end{tabular}

Karachunivs'ke reservoir with a total volume of about 120,0 million m3. The dis-placement of highly mineralized water from the river bed of the Ingulets River (completion of flushing) was carried out from June 5 to 25 . In the period from April 20 to June 30, the Kakhovka hydroelectric station was operated in the basic mode with the lowest possible costs, the value of which was established in the working order depending on the hydrological situation in the Lower Section of the Dnieper River for the period of saline prism pushing out of the Lower Section of the Ingulets River. 
During the observation period, the ecological state of the Lower Section of the Ingulets River in time and in space (along the river stream) is estimated as unsteady. Dynamics of quantitative parameters of mean and minimum coefficients demonstrates deterioration of river water quality in time. For the observation period 2013-2016, the environmental reliability (ER) was assessed in time and in space (along the river stream). The values of environmental reliability were calculated $(\mathrm{ER}=0,74)$, which corresponds to a low level of self-purification potential and capability of restoration.

Changes in the quantitative indicators of the average and minimum coefficients demonstrate a slight deterioration in the quality of water in the section of the river downstream from village Arkhangel's'ke to town Snigurivka. This is due to the unstable mixing mode due to the significant sinuosity of the river bed. Characteristic loops of meanders 5-7 km long almost turn some sections of the river to the starting point, which leads to a deterioration in water quality. An additional factor determining the increase of IIES (Table 6) is the high degree of agricultural use of the area. The introduction of chemical plant protection products leads to soil contamination with toxic elements, and the run-off of water from the fields by the surface path and underground filtration contribute to the migration of carcinogens to the nearest water body (the Ingulets River). Further relative improvement in water quality indicators in the area of the village Dar'ivka (Table 6) is due to the reduce of the mineralization effect of the Dnieper water [15, p. 35].

Recovery of the processes which activate an ability of the Lower Section of the Dnieper River to cleanse itself is possible due to the optimization of the regime of Kakhovka HPS-1 releases [3, p. 80; 5, p. 123; 1, p. 263] and/or building Kakhovka HPS-2 [16, p. 61]. According to the calculations of the Institute of Hydrobiology of the National Academy of Sciences of Ukraine approximately twice the size of the design (at a discharge of $5100 \mathrm{~m} 3 / \mathrm{s}$ ) of the velocity of flow in the river bed and the arms of the Dnieper River. The external water exchange of the zone channel network will intensify the period of its external water exchange will decrease from 11,4-17,2 to $5,8-8,8$ days (values are given for 6 and 4-hour releases, respectively).

\section{Conclusions}

1. Ecological state of the Lower Section of the Dnieper River (including the Lower Section of the Ingulets River) was estimated by method of 
calculation of integrated index on the basis of monitoring over the years 2001-2016 of surface waters of the Kherson Water Resources Board, the State Ecological Inspectorate in Kherson region and the State Ecological Inspectorate in Mykolaiv region.

2. Methodology for assessing the quality of surface water by hydrochemical parameters in accordance with the fishery standards as the most sensitive to changes of the ecological state of the river was used. The modern calculation method takes into account the effect of the total action of substances.

3. Self-purification potential and capability of restoration in time and space (along the river stream) of the aquatic ecosystem of the Lower Section of the Dnieper River and of the Lower Section of the Ingulets River were established. It was discovered, that the state of surface water of region was characterized as unsteady with the low of ecological reliability. Consequently, the processes of self-purification potential and capability of restoration of the aquatic ecosystem are at the low level.

4. The ecological state of the hydroecosystems of Low Podniproviya is characterized as an ecological regress.

5. Recovery of the processes which activate an ability of the Lower Section of the Dnieper River to cleanse itself is possible due to the optimization of the regime of Kakhovka HPS-1 releases and/or building Kakhovka HPS-2. The activation of the external water exchange will unambiguously increase the intensity of the river ability to cleanse water masses, will improve the water quality in the system of Low Podneproviya and the ecological state of the hydroecosystem.

6. The qualification of the ecological state of the Lower Section of the Dnieper River (including the Lower Section of the Ingulets River) determines the necessity to carry out environmental protection activities in the ecosystem (for example, reduce the volume of wastewater discharges, stop the enterprise, increase releases from Kakhovka reservoir, etc.).

7. The research results presented in this article can be the basis for establishing trends changes in the ecological state of the surface waters of the Lower Section of the Dnieper River (including the Lower Section of the Ingulets River) in time and space, determining the impact of anthropogenic load on ecosystems of water bodies, estimating changes of water quality, informing the public, solving economic and social issues, related to the rational use of natural resources and ensuring environmental protection. 


\section{References:}

1. Timchenko V., Oksiyuk O. (2002). Ecosystem condition and water quality control at impounded sections of rivers by the regulated hydrological regime. Ecohydrology and Hydrobiology, vol. 2, pp. 259-264.

2. Dubnyak S., Timchenko, V. (2000). Ecological role of hydrodynamic processes in the Dnieper reservoirs. Ecological Engineering, vol. 16, no 1, pp. 181-188.

3. Timchenko V.M., Korzhov Ye.I., Guliayeva O.A., Batog S.V. (2015). Dynamics of environmentally significant elements of hydrological regime of the lower Dnieper section. Hydrobiological Journal, vol. 51, issue 6, pp. 75-83.

4. Shakhman I.A., Bystriantseva A.N. (2017). Assessment of Ecological State and Ecological Reliability of the Lower Section of the Ingulets River. Hydrobiological Journal, vol. 53, issue 5, pp. 103-109.

5. Timchenko V., Oksiyuk O., Gore J. (2000). A model for ecosystem state and water quality management in the Dnieper River delta. Ecological Engineering, vol. 16, no 1, pp. 119-125.

6. Shakhman I.A., Bystriantseva A.N. (2018). Assessment of ecological state and ecological reliability of the Lower section of the Dnieper River. 18th International Multidisciplinary scientific Geoconference SGEM (Albena, Bulgaria, July 2-8, 2018), vol. 18, pp. 113-119.

7. Pichura V.I., Malchykova D.S., Ukrainskij P.A., Shakhman I.A., Bystriantseva A.N. (2018). Anthropogenic Transformation of Hydrological Regime of The Dnieper River. Indian Journal of Ecology, vol. 45(3), pp. 445-453.

8. Anastasiia Bystriantseva, Iryna Shakhman and Maksym Bystriantsev (2019). Spatio-Temporal Representation of the Ecological State of the Surface Waters of the Lower Section of the Dnieper River using GIS Technologies. Proceedings of the 14th International Conference on ICT in Education, Research and Industrial Applications. Integration, Harmonization and Knowledge Transfer (Kherson, Ukraine, June 12-15, 2019). Volume I: Main Conference, pp. 127-140.

9. Timchenko Z.V. (2002). Vodnye resursy i ekologicheskoe sostoyanie malykh rek Kryma [Water resources and ecological states of small rivers of Crimea]. Simferopol: Dolya. (in Russian)

10. Gmurman V.E. (1979). Rukovodstvo $k$ resheniyu zadach po teorii veroyatnosti i matematicheskoy statistike [Guide to solving problems in probability theory and mathematical statistics]. Moscow: Vysshaya shkola. (in Russian)

11. Shakhman I.O., Pylypenko Ju.V., Bystrjanceva A.M. (2015). Ekologhichni aspekty khimichnogho zabrudnennja vodnykh resursiv r. Inghulecj $u$ transformovanomu seredovyshhi v mezhakh Mykolajivsjkoji oblasti. [Ecological aspects of chemical pollution of water resources of the Ingulets River in the transformed environment within the limits of the Nikolayev region]. Taurian Scientific Bulletin, no. 93, pp. 265-275.

12. Shakhman I.O., Loboda N.S. (2016). Otsinka yakosti vody u stvori r. Inhulets $\mathrm{m}$. Snihurivka za hidrokhimichnymy pokaznykamy [Water quality estimation at the gauge station of the Ingulets River, town of Snigurivka, by hydrochemical parameters]. Ukrainian Hydrometeorological Journal, no. 17, pp. 123-136. 
13. Shakhman I.O., Bystrjanceva A.M., Pichura V.I. (2017). Matematychne modeljuvannja ghidroekologhichnykh procesiv ta chyseljni rozrakhunky ghidrokhimichnogho rezhymu Nyzhnjogho Dnipra [Mathematical modeling of hydro-ecological processes and numerical calculations of the hydrochemical regime of the Lower Dnieper]. Taurian Scientific Bulletin, no. 99, pp. 260-269.

14. Pichura V.I., Shakhman I.O., Bystrjanceva A.M. (2018). Prostoro-chasova zakonomirnistj formuvannja jakosti vody v richci Dnipro [Spatio-temporal pattern of formation of water quality in the Dnieper River]. Scientific journal of NULES of Ukraine "Bioresources and nature management" vol. 10, № 1-2, pp. 44-57.

15. SherstiukN.P.(2014). Vplyv promyvkyr.Inhuletsnaperebih hidrokhimichnykh protsesiv ta vstanovlennia rivnovah [Influence of washing of Ingulets River on the course of hydrochemical processes and equilibrium establishment] Hydrology, hydrochemistry and hydroecology, vol. 2(33), 36, pp. 28-37.

16. Feasibility study. Final report. 1606-69-T7 (2015). Vykonannja proektnykh robit, rozrobka rozdilu "Ocinka vplyvu na navkolyshnje seredovyshhe" [Execution of design work, development of the section "Assessment of the environmental impact”]. Kharkiv: PUBLIC COMPANY UKGHIDROPROJECT. (in Ukrainian) 